\title{
Kajian Kuat Tekan Beton yang Menggunakan Agregat Alam Kabupaten Sarolangun
}

\author{
Azwarman', M. Nuklirullah', M. Anugrah Arrihan $^{3}$ \\ ${ }^{1,2}$ (Dosen Fakultas Teknik Sipil Universitas Batanghari Jambi \\ 3(Mahasiswa Teknik Sipil Universitas Batanghari Jambi \\ Email : warman2789@gmail.com
}

\begin{abstract}
Abstrak. Sirtu adalah singkatan dari pasir batu yang tersebar di daerah aliran sungai. Sirtu sering digunakan oleh masyarakat Sarolangun sebagai bahan agregat pembuatan beton kemudian akan di uji kuat tekan betonnya. Untuk mendapatkan nilai kuat tekan beton tersebut agregat sirtu yang digunakan akan di uji kuat tekan betonnya di laboratorium. Tujuan dari penelitian ini adalah untuk mengkaji kuat tekan beton mana yang lebih baik antara sirtu dengan gradasi menerus atau sirtu tanpa gradasi (langsung dari alam).
\end{abstract}

Kata kunci: Sirtu, Kuat Tekan Beton, Agregat.

\section{PENDAHULUAN}

Sirtu merupakan akumulasi pasir dan batuan yang terendapkan di daerah-daerah relatif rendah atau lembah. Sirtu biasanya merupakan bahan yang belum terpadukan dan biasanya tersebar di daerah aliran sungai. Penggunaan agregat sirtu ini sudah sering digunakan masyarakat, penulis memilih daerah Sarolangun. Karena di daerah tersebut sering menggunakan sirtu sebagai bahan struktur bangunan teknik seperti rumah dan jalan. Sirtu tersebut di ambil langsung dari sungai kemudian langsung di campurkan dengan semen untuk membuat struktur bangunan tersebut.

Mengacu pada latar belakang, penulis tertarik untuk meneliti hal tersebut dengan judul "Kajian Kuat Tekan Beton yang Menggunakan Agregat Alam Kabupaten Sarolangun" sirtu akan di jadikan bahan agregat pembuatan beton yang kemudian akan di uji nilai kuat tekan betonnya dengan agregat yang gradasinya menerus dan agregat tanpa gradasi (langsung dari alam).

Adapun manfaat penelitian ini adalah sebagai berikut :

1. Dengan penelitian ini penulis dapat mengetahui apakah sirtu didaerah Sarolangun dapat digunakan sebagai bahan campuran beton.

2. Untuk mengetahui nilai kuat tekan beton mana yang lebih kuat antara campuran beton agregat sirtu dengan gradasi menerus atau tanpa gradasi (langsung dari alam).

\section{METODE}

Metode dan Proses Perancangan

Tahapan penelitian penyusunan Kajian Kuat Tekan Beton Yang Menggunakan Agregat Alam Kabupaten Sarolangun (Sirtu) sebagai berikut :

1. Studi Literatur dan Konsultasi Dosen

2. Mempersiapkan Bahan

3. Uji Labroratorium Benda Uji

4. Pembuatan Benda Uji

5. Pengujian Kuat Tekan

6. Analisa Hasil dan Pelaporan

Lokasi penelitian di Laboratorium Fakultas Teknik Universitas Batanghari Jambi, Jalan Slamet Riyadi - Broni, Jambi.

Adapun material dan benda uji yang akan digunkan pada penelitian ini adalah sebagai berikut:

1. Sirtu ( pasir batu ) di ambil dari Sarolangun Kecamatan Ladang Panjang yang lolos saringan 2" untuk keadaan asli, sedangkan satu lagi menggunakan gradasi yang di susun atas perhitungan di Laboratorium Teknik Universitas Batanghari Jambi.

2. Air dari Laboratorium Teknik Universitas Batanghari Jambi sebagai campuran untuk pengecoran.

3. Semen tipe PCC merk Padang dari toko semen di Jambi.

4. Pengujian dilakukan pada umur $7,14,21$ dan 28 hari.

5. Pengujian menggunakan benda uji beton kubus.

6. Pembuatan benda uji sebanyak 16 buah. Untuk agregat dengan gradasi menerus dan agregat tanpa gradasi (langsung dari alam) masing-masing sebanyak 8 buah benda uji. 


\section{Langkah-Langkah Pengujian}

1. Persiapkan agregat untuk di uji kualitasnya.

2. Pengujian agregat berupa : Analisa saringan, berat isi, berat jenis, abrasi, lolos saringan No.200, impact test, crushing test, kadar lumpur, kotoran organik dan kadar air.

3. Setelah semua pengujian selesai dan didapat hasil kualitas agregatnya maka di rancang untuk pembuatan benda uji.

4. Dengan metode DOE (Department of Enviroment) di dapat kebutuhan masing-masing agregat semen dan air untuk pengecoran.

5. Kemudian lakukan pengecoran benda uji.

6. Cetak benda uji ke dalam mol, besok harinya buka dari cetakan.

7. Lakukan perawatan berupa perendaman ke dalam bak berisi air, dan untuk yang gradasi dari alam tidak dilakukan perawatan.

8. Ambil benda uji dari tempat penyimpanan, lap permukaannya dan kemudian timbang.

9. Letakan benda uji di mesin tekan.

10.Catat nilai terakhir yang timbul pada mesin tekan.

\section{Pembuatan Benda Uji}

Benda uji yang akan dibuat pada penelitian ini adalah kubus dengan panjang $150 \mathrm{~mm}$ x lebar $150 \mathrm{~mm}$ x Tinggi $150 \mathrm{~mm}$ pada umur 7, 14, 21, 28 hari masing-masing benda uji di buat sebanyak 2 buah jadi total semua benda Uji 16 buah. Dimana 8 benda uji dengan gradasi dan 8 benda uji tanpa gradasi.

\section{HASIL DAN PEMBAHASAN}

Agregat yang digunakan pada penelitian ini adalah sirtu dari daerah Sarolangun, Kecamatan Ladang Panjang. Ukuran nominal maksimum agregat ditatapkan 2" ( $50 \mathrm{~mm}$ ). Gradasi agregat menerus dibentuk berdasarkan Brithis Standard Untuk Agregat Gabungan. Susunan saringan yang digunakan adalah 2", 11/2", 3/4", No. 4, No. 25, No. 100 dan Pan. Kemudian timbang masing-masing kebutuhan jumlah agregat tiap saringan. Setelah semua agregat siap kemudaian timbang semen dan air sesuai jumlah kebutuhan, setelah itu lakukan pengecoran benda uji.

Untuk sirtu tanpa gradasi (langsung dari alam) hanya di saring menggunakan saringan 2". Kemudian utuk memisahkan antara halus dan kasar di pisah menggunakan saringan No. 4 untuk menentukan berat benda uji kasar dan halus yang di gunakan. Kemudian timbang agregat tersebut sesuai jumlah kebutuhan untuk pengecoran benda uji. Siapkan semen dan air untuk kemudian dilakuakn pengecoran benda uji.

Semen yang digunakan adalah semen padang (Portland Composite Cement) dan air yang digunaklan standar (PDAM), semen dan air yang digunakan tidak diuji.

\section{Analisa Pengujian Agregat}

Analisis pengujian agregat ini dilakukan untuk mengetahui agregat sirtu tersebut memenuhi syarat atau standar untuk di lakukan pengecoran pembuatan benda uji. Data-data tersebut di sajikan dalam tabel berikut ini.

Tabel 1. Hasil Pengujian Agregat Campuran

\begin{tabular}{|c|c|c|c|c|c|c|}
\hline \multirow{2}{*}{ No } & \multirow{2}{*}{ Macam Pengujian } & \multicolumn{2}{|c|}{ Hasil Uji } & \multirow{2}{*}{ Syarat Mutu } & \multirow{2}{*}{$\begin{array}{l}\text { Metode Uji / } \\
\text { Standard }\end{array}$} & \multirow{2}{*}{ Ket } \\
\hline & & Sampel I & Sampel II & & & \\
\hline \multirow{5}{*}{1} & Berat Jenis Kasar & & & & \multirow{5}{*}{ SNI $1969: 2008$} & \\
\hline & - Berat Jenis Kering & 2,47 & 2,51 & & & \\
\hline & - Berat Jenis JPK & 2,51 & 2,54 & & & \\
\hline & - Berat Jenis Semu & 2,56 & 2,59 & & & \\
\hline & - Peresapan (\%) & 1,42 & 1,21 & & & \\
\hline \multirow{5}{*}{2} & Berat Jenis Halus & & & & \multirow{5}{*}{ SNI $1970: 2008$} & \\
\hline & - Berat Jenis Kering & 2,57 & 2,55 & & & \\
\hline & - Berat Jenis JPK & 2,60 & 2,58 & & & \\
\hline & - Berat Jenis Semu & 2,66 & 2,64 & & & \\
\hline & - Peresapan $(\%)$ & 1,21 & 1,42 & & & \\
\hline 3 & $\begin{array}{l}\text { Ketahanan Agregat Pada Keausan /Abrasi } \\
\text { Test }(\%)\end{array}$ & 32,80 & 35,40 & $\operatorname{Max} 40 \%$ & SNI $2417: 2008$ & \\
\hline 4 & $\begin{array}{l}\text { Ketahanan Agregat Pada Tumbukan /Impact } \\
\text { Test }(\%)\end{array}$ & 20,30 & 20,43 & $20 \%-30 \%$ & SNI 03-4426-1997 & \\
\hline \multirow{3}{*}{5} & Berat Isi & & & & \multirow{3}{*}{ ASTM C 29/29M-91a } & \\
\hline & - Lepas (Kg/Liter) & 1,70 & 1,73 & & & \\
\hline & - Padat (kg/Liter) & 1,80 & 1,80 & & & \\
\hline 6 & Kadar Lumpur (\%) & 0,34 & 1,05 & $\operatorname{Max} 1 \%$ & ASTM C-142-97 & \\
\hline 7 & Benda Uji Lolos Saringan No. 200 (\%) & 0,77 & 0,99 & & SNI 03-4142-1996 & \\
\hline
\end{tabular}


$8 \quad$ Pengujian Ketahanan Agregat Terhadap

Tekanan /Chrusing (\%)

Analisa Saringan

2"

$11 / 2^{\prime \prime}$

$93 / 4^{\prime \prime}$

No. 4

No. 25

No. 100

$\begin{array}{ccc}27,37 & 24,64 & \text { Max } 40 \% \\ & & \\ 100,00 & 100,00 & 100 \\ 91,64 & 93,78 & 95-100 \\ 64,81 & 58,81 & 45-80 \\ 31,85 & 29,68 & 25-50 \\ 12,38 & 11,50 & 30-\text { Aug } \\ 0,72 & 0,71 & 0-8\end{array}$

SNI 03-1968-1990

$0-8$

Tabel 2. Pemeriksaan Fisik Agregat

\begin{tabular}{ccc}
\hline Pemeriksaan Fisik Agregat & Gradasi Menerus & Tanpa Gradasi \\
\hline Berat Isi Padat (kg/liter) & 2,05 & 1,8 \\
Berat Jenis Sirtu & 2,56 & 2,54 \\
\hline
\end{tabular}

Sumber: Pengujian Di Laboratorium Teknik UNBARI (2018)

Tabel 3. Pemeriksaan

Berat Percobaan : 690,5

\begin{tabular}{|c|c|c|c|c|}
\hline \multirow{2}{*}{ Ukuran Saringan } & \multicolumn{2}{|c|}{ Berat Tertinggal } & \multirow{2}{*}{$\begin{array}{c}\text { Persentasi Tertinggal } \\
\%\end{array}$} & \multirow{2}{*}{$\begin{array}{c}\text { Persentase Melalui } \\
\%\end{array}$} \\
\hline & Gram & $\%$ & & \\
\hline No. 4 & 0,00 & 0,00 & 0,00 & 100,00 \\
\hline No. 8 & 74,00 & 10,81 & 10,81 & 89,19 \\
\hline No. 16 & 164,50 & 24,03 & 34,84 & 65,16 \\
\hline No. 25 & 160,50 & 23,45 & 58,29 & 41,71 \\
\hline No. 50 & 121,50 & 17,75 & 76,04 & 23,96 \\
\hline No. 100 & 103,00 & 15,05 & 91,09 & 8,91 \\
\hline Pan & 61,00 & 8,91 & 100,00 & 0,00 \\
\hline Total & 684,50 & 100,00 & 271,07 & 328,93 \\
\hline
\end{tabular}

Modulus Kehalusan = 2,71

Sumber: Pengujian Di Laboratorium Teknik UNBARI (2018)

Tabel 4. Tipe Modulus Kehalusan

\begin{tabular}{lcccc}
\hline Ukuran Saringan & $\begin{array}{c}\text { Kasar } \\
\text { Type I }\end{array}$ & $\begin{array}{c}\text { Agak Kasar } \\
\text { Type II }\end{array}$ & $\begin{array}{c}\text { Halus } \\
\text { Type III }\end{array}$ & $\begin{array}{c}\text { Agak Halus } \\
\text { Type IV }\end{array}$ \\
\hline No. 4 & 100 & 100 & 100 & 100 \\
No. 8 & $90-100$ & $90-100$ & 100 & $95-100$ \\
No. 16 & $60-95$ & $75-100$ & $90-100$ & $95-100$ \\
No. 25 & $30-70$ & $55-90$ & $85-100$ & $90-100$ \\
No. 50 & $15-34$ & $35-59$ & $75-100$ & $80-100$ \\
No. 100 & $5-20$ & $8-30$ & $60-79$ & $15-50$ \\
Pan & $0-10$ & $0-10$ & $12-40$ & $0-15$ \\
\hline
\end{tabular}

Sumber: Pengujian Di Laboratorium Teknik UNBARI (2018)

Berikut ini adalah langkah perhitungan perencanaan campuran beton untuk $1 \mathrm{~m}^{3}$. Menggunakan metode DOE (Department of Environment), yaitu :

1) Nilai kuat tekan beton yang direncanakan adalah K-225. Kuat tekan ini ditentukan pada umur 28 hari, dengan kegagalan/cacat maksimum $5 \%$ faktor $(\mathrm{k}=1,64)$.

2) Standar deviasi (S) dipakai $50 \mathrm{~kg} / \mathrm{cm}^{2}$ pada tabel 5.

Tabel 5. Deviasi Standar Mutu

\begin{tabular}{ccccc}
\hline & Isi Pekerjaan & \multicolumn{2}{c}{ Deviasi Standar $(\mathrm{kg} / \mathrm{cm} 2)$} & Dapat Diterima \\
\hline Sebutan & Volume Beton $(\mathrm{m} 3)$ & Baik Sekali & $55<\mathrm{S}<65$ & $66<\mathrm{S}<85$ \\
Kecil & $<1000$ & $45<\mathrm{S}<55$ & $45<\mathrm{S}<55$ & $65<\mathrm{S}<75$ \\
Sedang & $1000-3000$ & $35<\mathrm{S}<45$ & $35<\mathrm{S}<45$ & $45<\mathrm{S}<65$ \\
Besar & $>3000$ & $25<\mathrm{S}<35$ & \\
\hline
\end{tabular}

Sumber: Concrete Guide Sari Teknik Beton Untuk Jembatan (2018) 
3) Nilai margin, $\mathrm{M}=\mathrm{k} . \mathrm{S}=1,64 \times 50 \mathrm{~kg} / \mathrm{cm}^{2}=82 \mathrm{~kg} / \mathrm{cm}^{2}$.

4) Kuat tekan rata-rata yang ditargetkan, $F ' c r=f^{\prime} c+M=225+82 \mathrm{~kg} / \mathrm{cm}^{2}=307 \mathrm{~kg} / \mathrm{cm}^{2}$.

5) Semen yang digunakan adalah Semen tipe PCC merk Padang.

6) Agregat yang digunakan adalah agregat campuran yaitu sirtu alami tanpa dipecah.

7) Faktor Air semen (fas) di dapat 0,46. Dari tabel 6 dan gambar 3.

Tabel 6. Perkiraan Kuat Tekan Beton Dengan Fas 0,5

\begin{tabular}{|c|c|c|c|c|c|c|}
\hline \multirow{2}{*}{ Jenis Semen } & \multirow{2}{*}{ Jenis Agregat Kasar } & \multicolumn{4}{|c|}{ Kekuatan Tekan (Mpa), Pada Umur (Hari) } & \multirow{2}{*}{ Bentuk Benda Uji } \\
\hline & & 3 & 7 & 28 & 91 & \\
\hline \multirow{4}{*}{$\begin{array}{l}\text { Semen Portland Tipe I atau Semen } \\
\text { Tahan Sulfur Tipe II, V }\end{array}$} & Batu Tak Dipecah & 17 & 23 & 33 & 40 & \multirow{2}{*}{ Silinder } \\
\hline & Batu Pecah & 19 & 27 & 37 & 45 & \\
\hline & Batu Tak Dipecah & 20 & 28 & 40 & 48 & \multirow{2}{*}{ Kubus } \\
\hline & Batu Pecah & 23 & 32 & 45 & 54 & \\
\hline \multirow{4}{*}{ Semen Portland tipe III } & Batu Tak Dipecah & 21 & 28 & 38 & 44 & \multirow{2}{*}{ Silinder } \\
\hline & Batu Pecah & 25 & 33 & 44 & 48 & \\
\hline & Batu Tak Dipecah & 25 & 31 & 46 & 53 & \multirow{2}{*}{ Kubus } \\
\hline & Batu Pecah & 30 & 40 & 53 & 60 & \\
\hline
\end{tabular}

Sumber: Concrete Guide Sari Teknik Beton Untuk Jembatan.(2018)

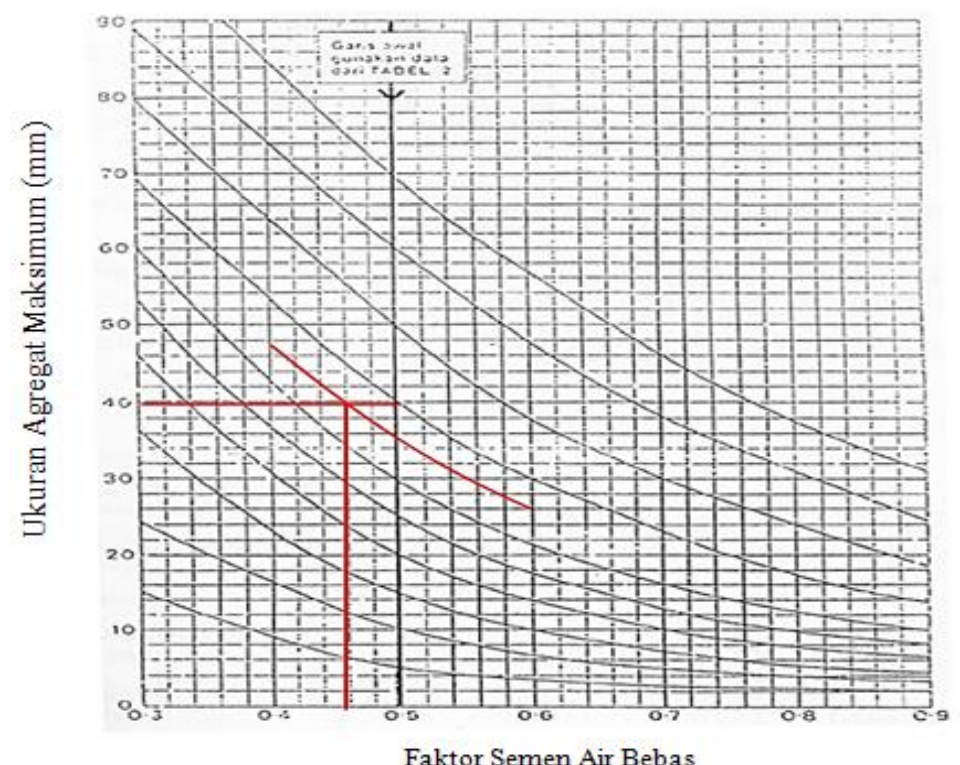

Gambar 1. Grafik Fas

Sumber : Pengolahan Data (2018)

8) Tetapkan fas maksimum 0,6 dengan acuan kondisi lingkungan pembetonan, yaitu terlindung dari hujan dan terik matahari secara lansung.

9) Pilih fas terkecil dari langkah 7 dan 8.

10) Nilai slump 30-60 mm.

11) Ukuran agregat maksimum adalah $40 \mathrm{~mm}$.

12) Kadar air bebas dari tabel 7 di dapat untuk ukuran butir agregat maksimum $40 \mathrm{~mm}$ batu tak di pecah slump 30-60 $\mathrm{mm}$ maka kadar air bebasnya adalah $160 \mathrm{~kg} / \mathrm{m}^{3}$.

Tabel 7. Perkiraan Kadar Air Bebas (Kg/m3)

\begin{tabular}{|c|c|c|c|c|c|}
\hline \multirow{2}{*}{$\begin{array}{c}\text { Ukuran Besar Butir Agregat } \\
\text { Maksimum }\end{array}$} & \multirow{2}{*}{ Jenis Agregat } & \multicolumn{4}{|c|}{ Slump (mm) } \\
\hline & & $0-10$ & 30-Oct & $30-60$ & $60-180$ \\
\hline \multirow{2}{*}{$10 \mathrm{~mm}$} & Batu Tak Dipecah & 150 & 180 & 205 & 225 \\
\hline & Batu Pecah & 180 & 205 & 230 & 250 \\
\hline \multirow{2}{*}{$20 \mathrm{~mm}$} & Batu Tak Dipecah & 135 & 160 & 180 & 195 \\
\hline & Batu Pecah & 170 & 190 & 210 & 225 \\
\hline \multirow{2}{*}{$40 \mathrm{~mm}$} & Batu Tak Dipecah & 115 & 140 & 160 & 175 \\
\hline & Batu Pecah & 155 & 175 & 190 & 205 \\
\hline
\end{tabular}

Sumber : Concrete Guide Sari Teknik Beton Untuk Jembatan (2018) 
13) Jumlah semen $=$ kadar air : fas $=160 \mathrm{~kg} / \mathrm{m}^{3}: 0,46=348 \mathrm{~kg} / \mathrm{m}^{3}$.

14) Presentasi agregat halus untuk agregat gradasi menerus adalah $37,50 \%$ dan untuk agregat tanpa gradasi adalah $30,77 \%$ sesuai dengan data analisa saringan pada pengujian labor.

15) Berat jenis relatif untuk agergat gradasi disusun adalah 2,56 dan untuk agregat tanpa gradasi adalah 2,54 .

16) Berat isi beton segar menurut gambar grafik 4 dan 5 untuk agregat gradasi menerus adalah $2387,5 \mathrm{~kg}$ dan untuk agregat tanpa gradasi adalah $2375 \mathrm{~kg}$.

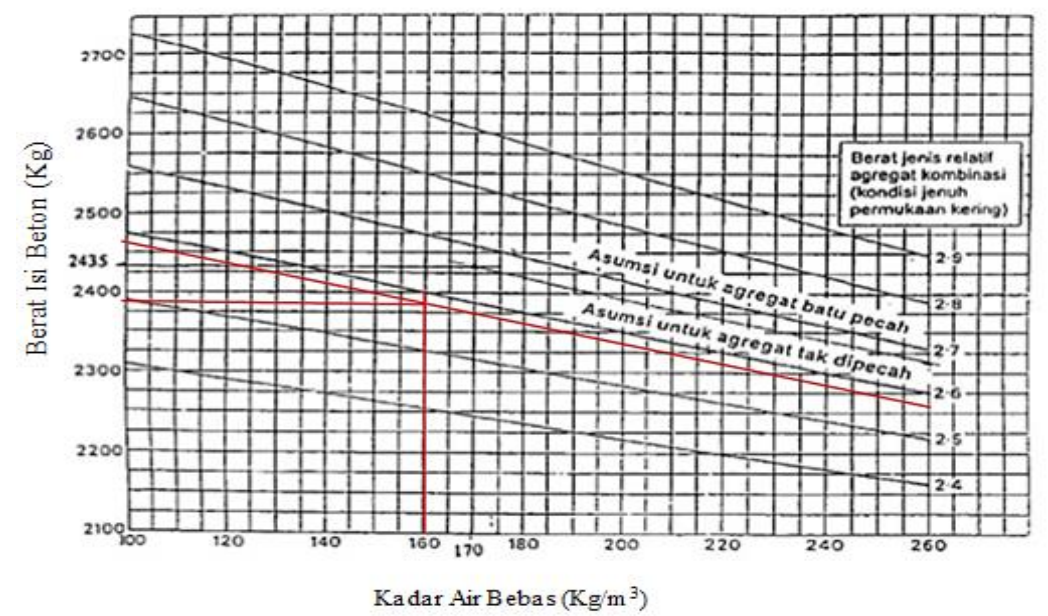

Gambar 2. Grafik Kadar Air Bebas Agregat Gradasi Menerus (2018) Sumber : Pengolahan Data (2018)

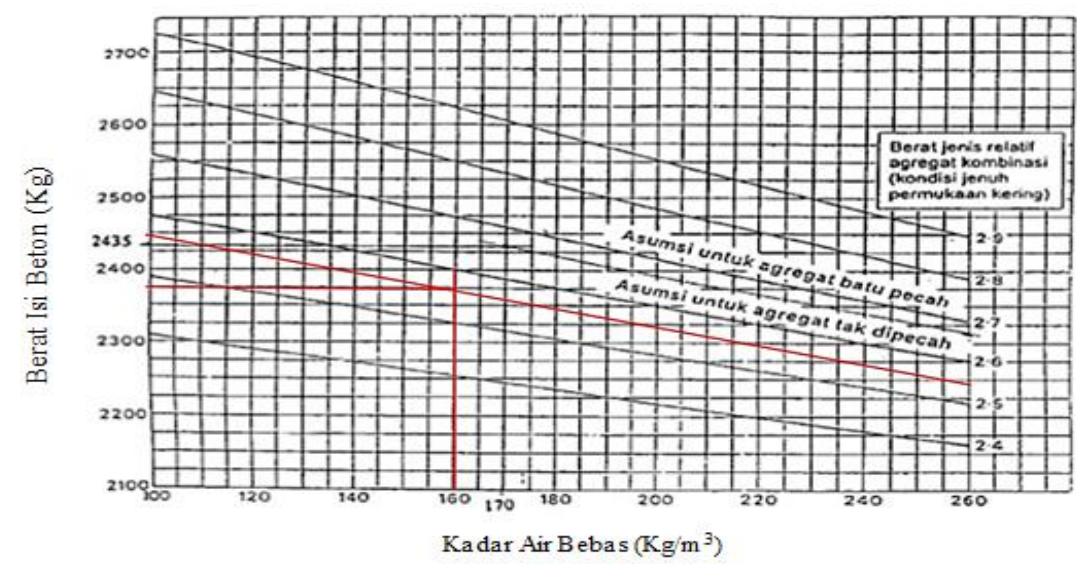

Gambar 3. Grafik Kadar Air Bebas Agregat Tanpa Gradasi (2018) Sumber : Pengolahan Data (2018)

17) Kadar agregat gabungan $=$ berat beton - jumlah $($ semen + air). Untuk agregat gradasi menerus $=2387,5 \mathrm{~kg}-(348$ $\mathrm{kg}-160 \mathrm{~kg})=1879,7 \mathrm{~kg}$. Untuk agregat tanpa gradasi $=2375 \mathrm{~kg}-(348 \mathrm{~kg}-160 \mathrm{~kg})=1867 \mathrm{~kg}$.

18) Kadar agregat halus $=\%$ agregat halus $\mathrm{x}$ kadar agregat gabungan. Untuk agregat gradasi menerus $=37,50 \% \mathrm{x}$ $1879,7 \mathrm{~kg}=704,89 \mathrm{~kg}$. Untuk agregat tanpa gradasi $=30,77 \%$ × $1867 \mathrm{~kg}=574,48 \mathrm{~kg}$.

19) Kadar agregat gabungan = agregat gabungan - agregat halus. Untuk agregat gradasi menerus $=1879,7 \mathrm{~kg}-$ $704,89 \mathrm{~kg}=1174,8 \mathrm{~kg}$. Untuk agregat tanpa gradasi $=1867 \mathrm{~kg}-574,48 \mathrm{~kg}=1292,52 \mathrm{~kg}$.

Hasil Perhitungan di sajikan dalam tabel berikut ini :

Tabel 8. Formulir Perencanaan Campuran Beton Agregat Gradasi Menerus

\begin{tabular}{clcl}
\hline NO & \multicolumn{1}{c}{ Uraian } & $\begin{array}{c}\text { Tabel / Grafik } \\
\text { Perhitungan }\end{array}$ & \multicolumn{1}{c}{ Nilai } \\
\hline 1 & Kuat tekan yang disyaratkan (benda uji kubus) & Ditetapkan & K225 pada 28 hari. Faktor (K=1,64) \\
2 & Deviasi standar & Diketahui & $50 \mathrm{~kg} / \mathrm{cm} 2$ \\
3 & Nilai tambah (Margin) & Faktor 1 x 2 & $1,64 \times 50=82 \mathrm{~kg} / \mathrm{cm} 2$ \\
4 & Kekuatan rata-rata yang ditargetkan & $1+3$ & $225+82=307 \mathrm{~kg} / \mathrm{cm} 2$ \\
5 & Jenis semen & Ditetapkan & PCC merk Padang \\
6 & Jenis agregat (Kasar dan Halus) & Ditetapkan & Sirtu \\
7 & Faktor air semen bebas & Gambar 3 & 0,46
\end{tabular}




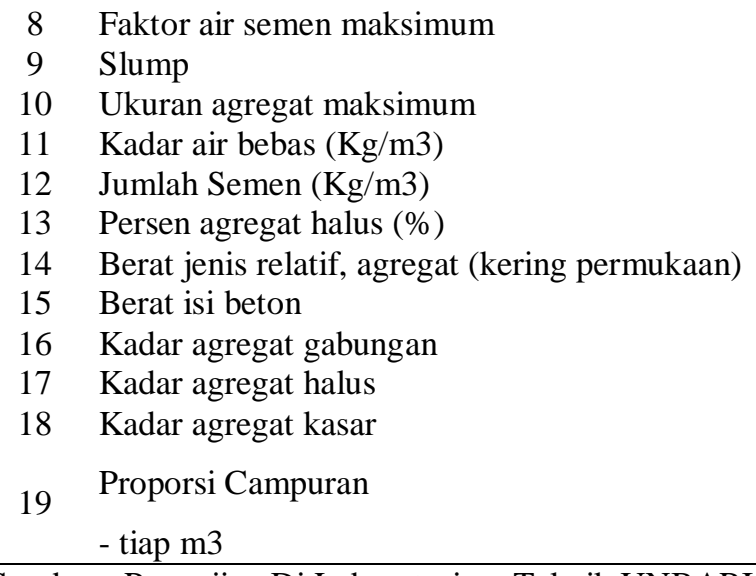

\begin{tabular}{|c|c|c|c|}
\hline \multicolumn{2}{|c|}{ Ditetankan } & \multicolumn{2}{|l|}{ (Ambil nilai yang terendah) } \\
\hline Ditet & kan & 0,6 & \\
\hline Ditet & kan & $30-60 \mathrm{~mm}$ & \\
\hline Ditet & kan & $40 \mathrm{~mm}$ & \\
\hline Tal & & & 160 \\
\hline $11: 8$ & tau 7 & & 348 \\
\hline Analisa & aringan & $37,5 \%$ & \\
\hline Penguj & labor & 2,56 & \\
\hline Gam & $\operatorname{ar} 4$ & 2387,5 & \\
\hline $15-($ & $+11)$ & $1879,7,2$ & \\
\hline 13 & & 704,9 & \\
\hline 16 & & 1174,8 & \\
\hline $\begin{array}{c}\text { Semen } \\
\left(\mathrm{Kg} / \mathrm{cm}^{3}\right) \\
348\end{array}$ & $\begin{array}{c}\text { Air } \\
\left(\mathrm{Kg} / \mathrm{cm}^{3}\right) \\
160\end{array}$ & $\begin{array}{c}\text { Agregat kondisi jenuh kering } \\
\text { permukaan }\left(\mathrm{Kg} / \mathrm{cm}^{3}\right) \\
1879,7\end{array}$ & \\
\hline
\end{tabular}

Tabel 9. Formulir Perencanaan Campuran Beton Agregat Gradasi dari Alam

\begin{tabular}{|c|c|c|c|}
\hline NO & Uraian & $\begin{array}{l}\text { Tabel / Grafik } \\
\text { Perhitungan }\end{array}$ & Nilai \\
\hline 1 & Kuat tekan yang disyaratkan (benda uji kubus) & Ditetapkan & K225 pada 28 hari. Faktor $(\mathrm{K}=1,64)$ \\
\hline 2 & Deviasi standar & Diketahui & $50 \mathrm{~kg} / \mathrm{cm} 2$ \\
\hline 3 & Nilai tambah (Margin) & Faktor 1 x 2 & $1,64 \times 50=82 \mathrm{~kg} / \mathrm{cm} 2$ \\
\hline 4 & Kekuatan rata-rata yang ditargetkan & $1+3$ & $225+82=307 \mathrm{~kg} / \mathrm{cm} 2$ \\
\hline 5 & Jenis semen & Ditetapkan & PCC merk Padang \\
\hline 6 & Jenis agregat (Kasar dan Halus) & Ditetapkan & Sirtu \\
\hline 7 & Faktor air semen bebas & Gambar 3 & $\begin{array}{l}0,46 \\
\text { (Ambil nilai yang terendah) }\end{array}$ \\
\hline 8 & Faktor air semen maksimum & Ditetapkan & 0,6 \\
\hline 9 & Slump & Ditetapkan & $30-60 \mathrm{~mm}$ \\
\hline 10 & Ukuran agregat maksimum & Ditetapkan & $40 \mathrm{~mm}$ \\
\hline 11 & Kadar air bebas $(\mathrm{Kg} / \mathrm{m} 3)$ & Tabel 7 & 160 \\
\hline 12 & Jumlah Semen $(\mathrm{Kg} / \mathrm{m} 3)$ & $11: 8$ atau 7 & 348 \\
\hline 13 & Persen agregat halus $(\%)$ & Analisa saringan & $30,77 \%$ \\
\hline 14 & Berat jenis relatif, agregat (kering permukaan) & Pengujian labor & 2,54 \\
\hline 15 & Berat isi beton & Gambar 5 & 2375 \\
\hline 16 & Kadar agregat gabungan & $15-(12+11)$ & 1867,2 \\
\hline 17 & Kadar agregat halus & $13 \times 16$ & 574,5 \\
\hline 18 & Kadar agregat kasar & $16-17$ & 1292,6 \\
\hline 19 & $\begin{array}{l}\text { Proporsi Campuran } \\
\text { - tiap m3 }\end{array}$ & $\begin{array}{cc}\text { Semen } & \text { Air } \\
\left(\mathrm{Kg} / \mathrm{cm}^{3}\right) & \left(\mathrm{Kg} / \mathrm{cm}^{3}\right) \\
348 & 160\end{array}$ & $\begin{array}{c}\text { Agregat kondisi jenuh kering } \\
\text { permukaan }\left(\mathrm{Kg} / \mathrm{cm}^{3}\right) \\
1867,2\end{array}$ \\
\hline
\end{tabular}

Sumber : Pengujian Di Laboratorium Teknik UNBARI (2018)

\section{Perhitungan Untuk Pengecoran}

Perhitungan Untuk Gradasi Menerus

Persiapan pengecoran untuk 8 benda uji agregat gradasi menerus

- Jumlah benda uji

- Volume 1 buah kubus

- Jadi $0,003375 \mathrm{~m}^{3}$ x 8

- $0,027 \mathrm{~m}^{3} \times 1,3$

- Jumlah agregat sirtu yang diperlukan

- Jumlah air yang diperlukan

- Jumlah semen yang dibutuhkan

- Cari masing-masing berat pada tiap saringan dengan jumlah agregat sirtu 65,98 kg dikalikan persentasi tiap saringan.

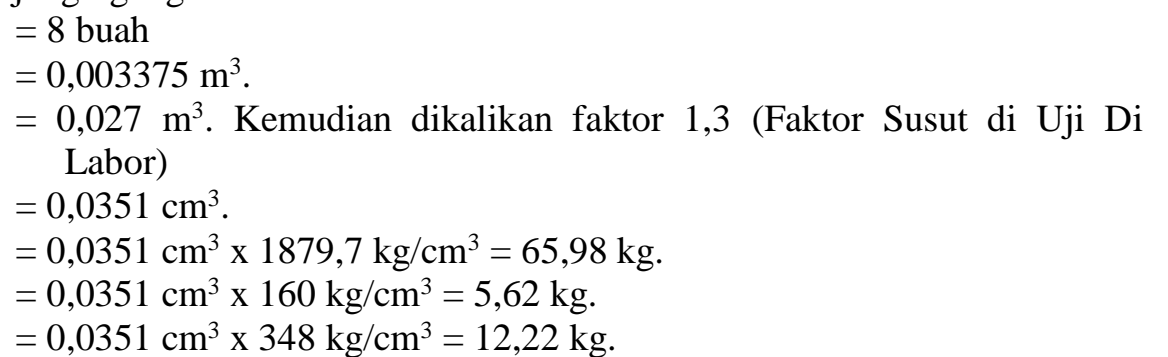$$
=0,003375 \mathrm{~m}^{3} \text {. }
$$$$
0,027 \mathrm{~m}^{3} \text {. Kemudian dikalikan faktor 1,3 (Faktor Susut di Uji Di }
$$$$
=0,0351 \mathrm{~cm}^{3} \times 1879,7 \mathrm{~kg} / \mathrm{cm}^{3}=65,98 \mathrm{~kg} \text {. }
$$$$
=0,0351 \mathrm{~cm}^{3} \times 348 \mathrm{~kg} / \mathrm{cm}^{3}=12,22 \mathrm{~kg} \text {. }
$$

K225 pada 28 hari. Faktor $(\mathrm{K}=1,64)$

$1,64 \times 50=82 \mathrm{~kg} / \mathrm{cm} 2$

PCC merk Padang

0,46

Ambil nilai yang terendah)

$30-60 \mathrm{~mm}$

60 8 
Tabel 10. Komposisi Campuran Agregat Menerus

\begin{tabular}{cll}
\hline NO & URAIAN & JUMLAH \\
\hline 1 & TOTAL AGREGAT SIRTU & $65,98 \mathrm{Kg}$ \\
2 & - AGREGAT KASAR & $41,23 \mathrm{Kg}$ \\
3 & - AGREGAT HALUS & $24,75 \mathrm{Kg}$ \\
4 & AIR & $5,62 \mathrm{Kg}$ \\
5 & SEMEN & $12,22 \mathrm{Kg}$ \\
\hline
\end{tabular}

Sumber : Pengujian Di Laboratorium Teknik UNBARI (2018)

Tabel 11. Jumlah Kebutuhan Saringan

\begin{tabular}{ccc}
\hline Saringan & $\%$ & Kebutuhan \\
\hline $11 / 2 "$ & $2,5 \%$ & 1,65 \\
No. 4 & $35 \%$ & 23,09 \\
No. 25 & $25 \%$ & 16,49 \\
No. 100 & $18,5 \%$ & 12,21 \\
Pan & $15 \%$ & 9,90 \\
Total & $4 \%$ & 2,64 \\
\hline
\end{tabular}

Sumber : Pengujian Di Laboratorium Teknik UNBARI (2018)

Kemudian cari faktor koreksi campuran.

Dari hasil perhitungan di atas di dapat kebutuhan masing-masing agregat, air dan semen. Namun dalam perhitungan diatas, agregat halus dan agregat kasar dianggap dalam keadaan jenuh kering permukaan (SSD), sehingga di lapangan yang pada umumnya keadaan agregatnya tidak jenuh kering muka, harus dilakukan koreksi terhadap kebutuhannya bahannya.

Berikut ini adalah hasil koreksi campuran tersebut :
B Jumlah Air
C Jumlah Agregat Halus
D Jumlah Agregat Kasar
CA Peresapan Agregat Halus
DA Peresapan Agregat Kasar
CK Kandungan Air Pada Agregat Halus
DK Kandungan Air Pada Agregat Kasar

$\begin{aligned} \mathrm{Kg} / \mathrm{M} 3 & =5,62 \\ \mathrm{Kg} / \mathrm{M} 3 & =24,75 \\ \mathrm{Kg} / \mathrm{M} 3 & =41,23 \\ \% & =2,04 \\ \% & =0,71 \\ \% & =0 \\ \% & =0\end{aligned}$

Rumus:
Koreksi Campuran Air
$\mathrm{B}$ - (Ck-Ca) x C/100 - (Dk-Da)xD/100 6,4176
Koreksi Agregat Halus
$\mathrm{C}+(\mathrm{Ck}-\mathrm{Ca}) \times \mathrm{C} / 100$
Koreksi Agregat Kasar
$\mathrm{D}+(\mathrm{Dk}-\mathrm{Da}) \times \mathrm{D} / 100$

Setelah diketahui kebutuhan bahan dan telah dilakukan penyaringan berat masing-masing agregat dan dilakukan koreksi campuran maka dilakukan proses pengecoran. Setelah pengecoran kemudian dilakukan penyetakan dengan mol kubus, setelah 24 jam lepas benda uji dari mol dan tunggu hingga hari pengujian kuat tekan benda uji.

\section{Perhitungan Untuk Agregat Gradasi dari Alam}

Persiapan pengecoran untuk 8 benda uji agregat tanpa gradasi

- Jumlah benda uji

- Volume 1 buah kubus

- Jadi $0,003375 \mathrm{~m}^{3}$ x 8

- $0,027 \mathrm{~m}^{3} \times 1,3$

- Jumlah agregat sirtu yang diperlukan

- Jumlah air yang diperlukan

- Jumlah semen yang dibutuhkan

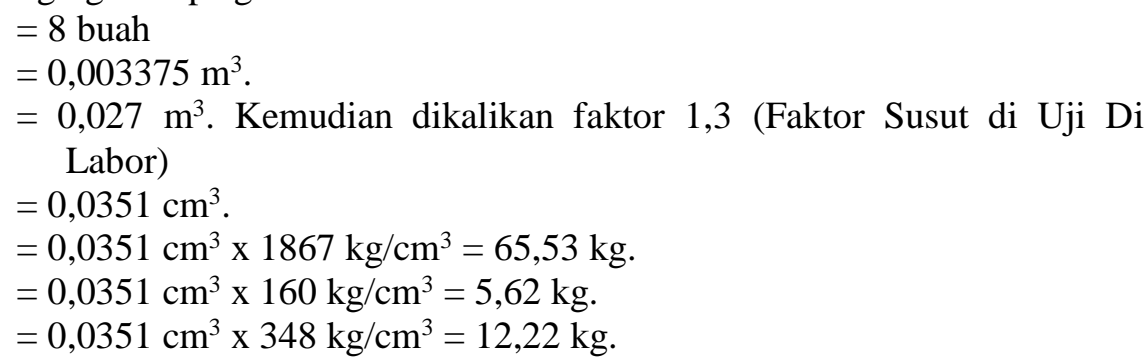

$=0,003375 \mathrm{~m}^{3}$.

0,027 $\mathrm{m}^{3}$. Kemudian dikalikan faktor 1,3 (Faktor Susut di Uji Di Labor)

$=0,0351 \mathrm{~cm}^{3}$.

$=0,0351 \mathrm{~cm}^{3} \times 160 \mathrm{~kg} / \mathrm{cm}^{3}=5,62 \mathrm{~kg}$.

$=0,0351 \mathrm{~cm}^{3} \times 348 \mathrm{~kg} / \mathrm{cm}^{3}=12,22 \mathrm{~kg}$. 
- Setelah diketahui kebutuhan bahan maka dilakukan penimbangan. Kemudian di lakukan pengecoran sebanyak 65,53 kg agregat sirtu, 5,62 kg air, dan 12,22 kg semen tanpa diperhitungkan analisa saringannya. Setelah itu sama seperti diatas tunggu sampai hari pengujian kuat tekan.

\section{Hasil Uji Kuat Tekan Beton}

Berikut ini merupakan hasil pengujian nilai kuat tekan beton benda uji kubus dengan masing-masing berumur 7 , 14, 21 dan 28 hari. Hasil uji dilihat dari tabel berikut :

Tabel 12. Kuat Tekan Beton Agregat Gradasi Menerus

\begin{tabular}{cccc}
\hline Umur Beton (Hari) & Kuat Tekan Beton $(\mathrm{KN})$ & Kuat Tekan Aktual $\left(\mathrm{Kg} / \mathrm{cm}^{2}\right)$ & Rata-Rata Kuat Tekan Aktual $\left(\mathrm{Kg} / \mathrm{cm}^{2}\right)$ \\
\hline 7 & 443,3 & 200,963 & 201,915 \\
7 & 447,5 & 202,867 & 219,368 \\
14 & 474,9 & 215,288 & 245,004 \\
21 & 492,9 & 223,448 & 248,744 \\
21 & 538,6 & 244,165 & \\
28 & 542,3 & 245,843 & 245,843 \\
28 & 542,3 & 251,645 & 2 \\
\hline
\end{tabular}

Sumber : Pengujian Di Laboratorium Teknik UNBARI (2018)

Tabel 13. Kuat Tekan Beton Agregat Tanpa Gradasi

\begin{tabular}{cccc}
\hline Umur Beton (Hari) & Kuat Tekan Beton $(\mathrm{KN})$ & Kuat Tekan Aktual $\left(\mathrm{Kg} / \mathrm{cm}^{2}\right)$ & Rata-Rata Kuat Tekan Aktual $\left(\mathrm{Kg} / \mathrm{cm}^{2}\right)$ \\
\hline 7 & 307,3 & 139,309 & 155,403 \\
14 & 378,3 & 171,496 & 196,429 \\
14 & 418,4 & 189,675 & 229,387 \\
21 & 448,2 & 203,184 & 240,267 \\
21 & 504,7 & 228,797 & 229,976 \\
28 & 507,3 & 236,368 & \\
\hline
\end{tabular}

Sumber: Pengujian Di Laboratorium Teknik UNBARI (2018)

$* 1 \mathrm{kN}=102 \mathrm{~kg} \quad$ Luas Bidang $=225 \mathrm{~cm} 2$

Tabel 14. Nilai Kuat Tekan Beton Aktual

\begin{tabular}{ccccc}
\hline Gradasi Agregat & \multicolumn{4}{c}{ Kuat Tekan Aktual Rata-Rata Kg/cm ${ }^{2}$} \\
& 7 Hari & 14 Hari & 21 Hari & 28 Hari \\
\hline Gradasi Menerus & 201,915 & 219,368 & 245,004 & 248,744 \\
Gradasi Dari Alam & 155,403 & 196,429 & 229,387 & 240,267 \\
\hline
\end{tabular}

Sumber : Pengujian Di Laboratorium Teknik UNBARI (2018)

Tabel 15. Persentase Nilai Kuat Tekan

\begin{tabular}{ccccc}
\hline Gradasi Agregat & Persentase (\%) & 21 Hari & 28 Hari \\
& 7 Hari & 14 Hari & 74,7 & 76,58 \\
Gradasi Menerus & 47,96 & 60,05 & 66,17 & 72,22 \\
Gradasi Dari Alam & 2,45 & 43,71 & 6 \\
\hline
\end{tabular}

* Nilai Target $307 \mathrm{Kg} / \mathrm{cm} 2$

Sumber : Pengujian Di Laboratorium Teknik UNBARI (2018)

\section{SIMPULAN}

1. Hasil perencanaan campuran beton dengan gradasi menerus memerlukan agregat sebanyak $65,98 \mathrm{~kg}$. Sedangkan campuran beton gradasi dari alam memerlukan agergat sebanyak $65,53 \mathrm{~kg}$. Presentase agregat halus pada gradasi menerus adalah $37,50 \%$ sedangkan presentase agregat halus pada gradasi dari alam adalah $30,77 \%$.

2. Nilai kuat tekan beton yang di syaratkan adalah nilai kuat tekan rencana yaitu $225 \mathrm{~kg} / \mathrm{m}^{2}$ bukan nilai target yaitu $307 \mathrm{~kg} / \mathrm{m}^{2}$. Nilai target berguna untuk memperbesar nilai kuat tekan rencana pada pembuatan campuran beton dilapangan.

3. Hasil dari nilai kuat tekan beton dari gradasi menerus lebih besar dari gradasi dari alam.

4. Untuk gradasi menerus nilai kuat tekan beton pada umur 7 hari sebesar $201,915 \mathrm{~kg} / \mathrm{m}^{2}$ dengan persentasi $47,96 \%$ dari nilai kuat tekan target. Nilai kuat tekan beton pada umur 14 hari sebesar $219,368 \mathrm{~kg} / \mathrm{m}^{2}$ dengan persentasi $60,05 \%$ dari nilai kuat tekan target. Nilai kuat tekan beton pada umur 21 hari sebesar 245,004 kg/m² dengan 
persentasi $74,7 \%$ dari nilai kuat tekan target. Nilai kuat tekan beton pada umur 28 hari sebesar $248,744 \mathrm{~kg} / \mathrm{m}^{2}$ dengan persentasi $76,58 \%$ dari nilai kuat tekan target.

5. Untuk gradasi dari alam nilai kuat tekan beton pada umur 7 hari sebesar $155,403 \mathrm{~kg} / \mathrm{m}^{2}$ dengan persentasi $2,45 \%$ dari nilai kuat tekan target. Nilai kuat tekan beton pada umur 14 hari sebesar $196,429 \mathrm{~kg} / \mathrm{m}^{2}$ dengan persentasi $43,71 \%$ dari nilai kuat tekan target. Nilai kuat tekan beton pada umur 21 hari sebesar $229,387 \mathrm{~kg} / \mathrm{m}^{2}$ dengan persentasi $66,17 \%$ dari nilai kuat tekan target. Nilai kuat tekan beton pada umur 28 hari sebesar $240,267 \mathrm{~kg} / \mathrm{m}^{2}$ dengan persentasi $72,22 \%$ dari nilai kuat tekan target.

6. Agregat sirtu ini masih bisa digunakan untuk bangunan teknik yang memiliki beban sedikit, seperti rumah tinggal tanpa tingkat.

\section{Saran}

1. Untuk merencanakan campuran beton lebih baik menggunakan sirtu dengan gradasi menerus, karena nilai kuat tekan betonnya sedikit lebih besar dari pada gradasi dari alam.

2. Dikarenakan hasil abrasi dari agregat sirtu ini sebesar 35\% hampir mencapai batas maksimun yaitu $40 \%$ maka perlu dilakukan penelitian lebih lanjut mengenai penambahan semen dalam campuran agregat sirtu ini agar hasil nilai kuat tekan beton yang dicapai lebih meningkat.

\section{DAFTAR PUSTAKA}

Mulyono, T., 2004., Teknologi Beton, Andi, Yogyakarta.

Nugraha, P dan Antoni, Adi K., 2007., Teknologi Beton. Andi, Yokyakarta.

SNI 03-1968-1990. Metode Pengujian Tentang Analisa Saringan Agregat Halus Dan Kasar. Badan Standardisasi Nasional (BSN).

SNI 1969 : 2008. Cara Uji Berat Jenis Dan Penyerapan Air Agregat Kasar. Badan Standardisasi Nasional (BSN).

SNI 1970 : 2008. Cara Uji Berat Jenis Dan Penyerapan Air Agregat Halus. Badan Standardisasi Nasional (BSN).

SNI 03-1971-1990. Metode Pengujian Kadar Air Agregat. Badan Standardisasi Nasional (BSN).

SNI 2417 : 2008. Cara Uji Keausan Agregat Dengan Mesin Abrasi Los Angeles. Badan Standardisasi Nasional (BSN).

SNI 03-4142-1996. Metode Pengujian Jumlah Bahan Dalam Agregat Yang Lolos Saringan No.200. Badan Standardisasi Nasional (BSN).

SNI 03-4426-1997. Metode Pengujian Ketahanan Agregat Dengan Alat Tumbuk. Badan Standardisasi Nasional (BSN).

SNI 03-4804-199. Metode Pengujian Bobot Isi Dan Rongga Udara Dalam Agregat. Badan Standardisasi Nasional (BSN). 